\title{
Simulation of metal-graphene composites by molecular dynamics: a review
}

\author{
L. R. Safina ${ }^{1}$, J. A. Baimova ${ }^{\dagger, 2,3}$, K. A. Krylova ${ }^{2,3}$, R. T. Murzaev², R. R. Mulyukov'1,2 \\ †julia.a.baimova@gmail.com
}

\begin{abstract}
${ }^{1}$ Ufa State Petroleum Technological University, 1 Kosmonavtov St., Ufa, 450062, Russia ${ }^{2}$ Institute for Metals Superplasticity Problems RAS, 39 S. Khalturin St., Ufa, 450001, Russia

${ }^{3}$ Bashkir State University, 32 Zaki Validi St., Ufa, 450076, Russia
\end{abstract}

\begin{abstract}
Fabrication of the new composite materials with improved mechanical characteristics is of high interest nowadays. Simulation methods can considerably improve understanding of the interaction between the graphene and metal phase, even in the atomistic level. In the present work, the simulation of graphene-metal composites by molecular dynamics is reviewed. Both experiments and simulation results have shown that the metal matrix can be reinforced with graphene flakes, and the overall mechanical properties of the final composite structure can be significantly improved. Two basic types of metal-graphene composite structures are considered: (i) metal matrix strengthens by graphene flakes and (ii) crumpled graphene (the porous structure that consists of crumpled graphene flakes connected by van der Waals forces) as the matrix for metal nanoparticles. Several different types of interatomic potentials like pairwise Lennard-Jones or Morse or complex bond order potentials for the description of metal-carbon interaction are presented and discussed. It is shown that even simple interatomic potentials can be effectively used for the molecular dynamics simulation of graphene-metal composites. Particular attention is paid to graphene-Ni composites obtained by deformation and heat treatment from crumpled graphene with pores filled with $\mathrm{Ni}$ nanoparticles. It is shown, that high-temperature compression can be effectively used for the fabrication of the graphene-Ni composite with improved mechanical properties.
\end{abstract}

Keywords: crumpled graphene, Ni-graphene composite, hydrostatic pressure, molecular dynamics, mechanical properties.

УДК: 539.3

\section{Моделирование композитов металл-графен методом молекулярной динамики: обзор}

\author{
Сафина Л. Р. ${ }^{1}$, Баимова Ю. А. ${ }^{\dagger, 2,}$, Крылова К. А. ${ }^{2,3}$, Мурзаев Р. Т. ${ }^{2}$, Мулюков Р. Р. ${ }^{1,2}$ \\ ${ }^{1}$ Уфимский государственный нефтяной технический университет, ул. Космонавтов, 1, Уфа, 450062, Россия \\ ${ }^{2}$ Институт проблем сверхпластичности металлов РАН, ул. С. Халтурина, 39, Уфа, 450001, Россия \\ ${ }^{3}$ Башкирский государственный университет, ул. Заки Валиди, 32, Уфа, 450076, Россия
}

В настоящее время большой интерес вызывает создание новых композиционных материалов с улучшенными механическими свойствами. Методы моделирования могут значительно улучшить понимание взаимодействия графена с металлической фазой даже на атомистическом уровне. В настоящей работе дается обзор моделирования композитов графен-металл методом молекулярной динамики. Как экспериментальные, так и результаты моделирования показали, что металлическую матрицу можно значительно укрепить за счет чешуек графена и общие механические свойства конечной композитной структуры становятся намного лучше. Рассмотрены два основных типа композитных структур металл-графен: (i) металлическая матрица, усиленная чешуйками графена и (ii) смятый графен (пористая структура, состоящая из скомканных чешуек графена, соединенных между собой силами Ван-дерВаальса) как матрица для металлических наночастиц. В ходе обсуждения представлены несколько различных типов межатомных потенциалов, таких как парные потенциалы Леннарда-Джонса или Морзе и другие сложные потенциалы порядка связи для описания взаимодействия металл-углерод. Показано, что даже простые межатомные потенциалы 
могут быть эффективно использованы для молекулярно-динамического моделирования композитов графен-металл. Особое внимание уделено композиту графен-никель, полученному деформацией и термообработкой из скомконного графена, заполненного наночастицами никеля. Показано, что высокотемпературное сжатие может быть эффективно использовано для создания композита графен-никель с улучшенными механическими свойствами.

Ключевые слова: скомканный графен, композит Ni-графен, гидростатическое давление, молекулярная динамика, механические свойства.

\section{Introduction}

Interaction of carbon nanostructures and metal nanoparticles is of great interest nowadays because it offers wide opportunities in the production of new nanomaterials. The development of nanotechnologies rises up a new challenge to obtain nanoscale structures with improved electronic, thermal, and mechanical properties. Carbon nanotubes (CNTs) and graphene are considered as very promising materials for enhancing mechanical and other properties of metal-matrix composites. Devices such as biosensors [1], photoactive composites [2], and nanoelectronic devices [3] can be made on the basis of graphene and gold nanoparticles.

To date, numerous experimental and theoretical works are carried out to study the process of fabrication of nanocomposites, their mechanical and thermal properties. The advantage is that graphene-reinforced metal composites show improved properties even at low graphene content. As it was shown, metal adatoms on graphene surface serve as scattering centers which led to a decrease of graphene conductivity, while clustering of the adatoms increases the suppressed conductivity [4-9]. Graphene in the metal-graphene nanolayered structures can increase the strengths of the nanolayered composites, enhance the load carrying capacity of the metal substrate $[1,11]$. Although some of such composites are already being obtained in practice, there is no detailed understanding of how their properties can be improved by controlling the composition.

One of the important issues is the role of metal catalysts in the growth of carbon nanotubes and graphene using the method of chemical vapor deposition (CVD) [12-15]. In addition, graphene has recently been grown epitaxially on various metal surfaces such as nickel [16-18], copper [14], cobalt $[15,18]$ and ruthenium [17], and it has been revealed that there is a good epitaxy between the hexagonal graphite and close-packed facets of ccp and hcp metals.

Each of the currently proposed composites based on, for example, graphene layers in a metal matrix or carbon nanotubes embedded in a metal matrix, has its advantages and disadvantages, and one of the important tasks is to determine the possibility of improving properties (for example, conductivity or strength) by external influences such as deformation and temperature. The particular issues are the search for better fabrication techniques, improvement of the mechanical properties and strength of the metal-matrix composites, peculiarities of the structure during different treatment, details of interactions between molecules, to name a few.

However, experimental studies require lots of efforts like using special equipment or conduction of expensive and labor experiments. From this point of view, molecular dynamics
(MD) can be effectively used for studying different structural changes, especially for nanostructured materials. However, there are several different interatomic potentials, which can be used for the description of the interaction between graphene and metal atoms, like many-body embedded-atom model (EAM), ReaxFF etc., or simple pair Morse or LennardJones (LJ) potentials. Both approaches can have their pros and cons and thus should be used for specified problems, which will be discussed in the present work.

\section{Interatomic potentials for graphene-metal composites}

The potential of the carbon-metal (Me) system can be defined as the sum of three potential energies of carbon-carbon, carbon-Me and Me-Me interactions, correspondingly

$$
U_{\text {total }}=U_{\mathrm{C}-\mathrm{C}}+U_{\mathrm{Me}-\mathrm{Me}}+U_{\mathrm{C}-\mathrm{Me}} \text {. }
$$

The first part is for the description of interaction inside the graphene plane. For C-C interaction well-known potentials can be used like Tersoff or Brenner interatomic potential $[19,20]$ and AIREBO many-body interatomic potential [21]. The difference is that for AIREBO potential weak van-derWaals forces are already included, while for Brenner and Tersoff they should be added if required. Also, the choice of interatomic potential considerably depends on the simulated problem. Moreover, for Brenner and Tersoff potentials the existence of several sets of coefficients should be taken into account. However, these potentials showed good agreement with the experimental results and can be effectively used for studying mechanical properties, deformation behavior, thermal properties, etc. of carbon nanostructures [22-28].

The second term in Eq. (1) corresponds to the interaction between metal atoms. Commonly, it can be described by the embedded atom method (EAM) potential with parameters specified for the required metal. For some works, C-C interaction can also be described by EAM potential. Moreover, some modified potential functions can describe interaction in the Me-carbon system, for example, carbon-Ni [29-31].

For interaction between carbon and metal atoms several approaches can be used. The simplest way is to use pair interatomic potential, like Morse or LJ because of weak binding energy between some metals and graphene: LJ potential was used for $\mathrm{Cu}-\mathrm{C}$ interaction $[21,32,33]$, Au-C [34-34], Ni-C [35-37]. For a description of the interaction between graphene and $\mathrm{Ni}$, bond order potential developed by Shibuta and Maruyama was used [36]. This potential has been widely employed in the MD simulation of metal-catalyzed growth of single walled nanotubes [36], the graphitization ability of transition metals [40], 
the melting of nickel nanoparticles [42], formation of nickel-metallofullerenes [43], the bond-switching rate in nickel-carbon binary nanoclusters [44], and mechanical [45] and thermal properties [46] of the metal-coated carbon nanotubes. Interestingly, Brenner potential can be used not just for C-C interaction, but also for C-Ni interaction [47]. Crumpling of graphene flake around $\mathrm{Ni}$ nanoparticle can be sucsesfuuly studied by this potential and results are in good agreement with experimental results.

In [48], LJ potential is also used as an additional part to Tersoff potential to simulate C-C van-der-Waals interaction, while when using AIREBO potentials this part is already included.

Large-scale Atomic/Molecular Massively Parallel Simulator (LAMMPS) can be effectively used for any type of MD simulations [21-33] with different interatomic potentials.

Here, the results, obtained with the Morse $\left(U_{\mathrm{C}-\mathrm{Ni}}, U_{\mathrm{Ni}-\mathrm{Ni}}\right)$, AIREBO $\left(U_{\mathrm{C}-\mathrm{C}}\right)$ and ReaxFF $\left(U_{\text {total }}\right)$ potential are presented, thus, those functions are described more carefully. The second and third terms of Eq. (1) are calculated using Morse potential

$$
U_{\mathrm{C}-\mathrm{Me} / \mathrm{Me}-\mathrm{Me}}(r)=D_{\mathrm{e}}\left[\left(1-e^{-\alpha\left(r-r_{e}\right)}\right)^{2}-1\right],
$$

where $D_{e}$ is the binding energy, $r_{e}$ - equilibrium distance for a pair of atoms and a describes bond rigidity. Morse potential was previously successfully used for the investigation of crowdions and discrete breathers in twoand three-dimensional metal crystals [49], studying of the martensitic transformation $[50,51]$, the interaction of carbon polymorphs and Ni nanoparticles $[52,53]$ to name a few. Numerous MD simulations of $\mathrm{Ni}$ nanoparticles are conducted using EAM parameterization for the interatomic potential that reproduces reasonably well the properties of $\mathrm{Ni}$ clusters. Although the Morse potential is a simplification of a real system, it can give results that are physically significant.

The other approach is to study the system by one complex potential. Recently, parameters for $\mathrm{C}-\mathrm{Ni}$ were proposed for calculation with the potential of reactive force fields (ReaxFF) [54] using the example of graphene rolls wrapped around a metal nanoparticle. Such type of potential can be used to simulate carbon-based nanomaterials, including other elements, such as $\mathrm{H}, \mathrm{O}, \mathrm{N}, \mathrm{S}$ and some metals, such as $\mathrm{Ni}$, $\mathrm{Ag}, \mathrm{Au}$, etc. ReaxFF makes it possible to take into account the contributions to the energy of two-, three- and four-particle interactions, which describe covalent bonds and depend on the bond orders calculated by the empirical formula; take into account the valence of atoms; as well as electrostatic and dispersive contributions. All this determines the high accuracy of calculations.

The ReaxFF potential takes into account the following types of energy:

$$
\begin{aligned}
E_{\text {system }}= & E_{\text {bond }}+E_{\text {over }}+E_{\text {under }}+E_{\text {val }}+E_{\text {pen }}+E_{\text {coa }}+E_{\text {tors }}+ \\
& +E_{\text {conj }}+E_{\text {hbond }}+E_{\text {vdW }}+E_{\text {Coulomb }}+E_{\text {lp }} .
\end{aligned}
$$

Each term on the right-hand side of the formula is responsible for a different type of interaction: covalent (characterized by the order of chemical bonds, the terms $E_{\text {bond' }}$ $\left.E_{\text {over }}, E_{\text {under }}\right)$, three-particle (bond angles, $\left.E_{\text {val }}, E_{\text {pen }}, E_{\text {coa }}\right)$, fourparticle (dihedral bond angles, $\left.E_{\text {tors }}, E_{\text {conj }}\right)$, Coulomb $\left(E_{\text {Coulomb }}\right)$, van der Waals $\left(E_{\mathrm{vdW}}\right)$, hydrogen bonds $\left(E_{\mathrm{hbond}}\right)$, and energy of lone electron pairs $\left(E_{\mathrm{lp}}\right)$. All parameters of the potential are fitted to experimental measurements and calculated from quantum-mechanical calculations of the energy of bond lengths and angles.

To study the applicability of the Morse potential for modeling interaction in the nickel-carbon system the example of the interaction of a nickel nanoparticle and a graphene sheet is used. The parameters of the Morse potential for describing the interaction of nickel and carbon atoms were obtained by the ab-initio method $[55,56]$. The comparison is made based on the recently developed ReaxFF (Reactive Force Field) potential [54].

$\mathrm{Ni}$-graphene systems with Ni nanoparticle on the graphene sheet $16 \times 16 \AA$ are considered. The interaction between a particle and graphene strongly depends on the ratio of their sizes [54], thus, the graphene sheet with a side slightly smaller (16 $\AA$ ) than the nanoparticle diameter $(20 \AA)$ is studied. As shown $[55,56]$, the interaction between nickel and graphene is strong enough, as a result of which the attraction of the nanoparticle and the graphene sheet should occur. However, for the same simulation time ( $t=75 \mathrm{ps}$ ), the use of the model with the Morse potential leads to the complete unification of the Ni particle and the graphene sheet, and no visible changes occur in the model with ReaxFF.

Fig. 1 shows the final structures obtained by modeling with the Morse potential (Fig. 1a) and the ReaxFF potential (Fig. 1b) at $t=150$ ps. For Morse interaction with parameters obtained in [52], the nanoparticle itself loses its long-range crystalline order. Analysis showed that the Morse potential reproduces well the behavior of systems such as nickelcarbon. It should be noted that the ReaxFF potential gives the same result as the Morse potential, however, the simulation time with this potential increases many times.

It was found that the parameters of the Morse potential, selected for modeling nickel, lead to a loss of crystal order, and this does not happen when using the ReaxFF potential, which raises the question of finding more suitable parameters of the Morse potential for a nickel.

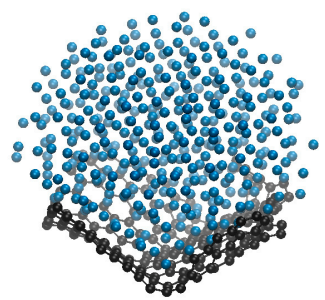

a

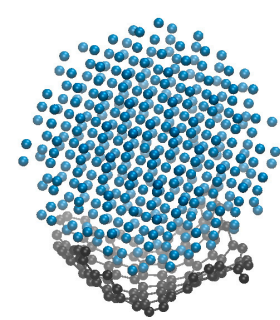

$\mathrm{b}$
Fig. 1. (Color online) Final structures at $t=150$ ps for the $\mathrm{Ni}$ nanoparticle on the graphene sheet model with Morse potential (a) and ReaxFF (b) [51].

\section{Graphene-metal composites}

\subsection{Graphene as strengthening element for metal matrix}

For metal matrix composites (MMC) the metal (Al, Cu, Ni) plays the role of matrix and the reinforcing element is ceramic or organic material. Owing to their perfect properties like 
high strength, low density, strengthened mechanical and thermal properties, MMCs are preferred in a wide range of applications. However, the strength and ductility of such composites can strongly depend on the type of strengthening element. Graphene or its derivatives from this point of view are very attractive and numerous theoretical and experimental studies have been conducted to date [63-65]. Review on the experimentally obtained results is presented in [65]. Examples of the experimentally obtained structures of graphene-metal matrix composites are presented in Fig. 2. Graphene can be observed as crumpled flakes inside the $\mathrm{Al}$ matrix, or it can be in the form of straight graphene layers alternating with metal layers. These two states are commonly used to obtain composites.

Recently, it was shown that graphene nanoflakes (GNFs) have great potential as an ideal reinforcement for aluminummatrix composites because of their ultra-high strength and wrinkled structure [63-65]. Graphene reinforcement increases tribological properties of copper, improve its mechanical and physical properties; hardness of Ti-matrix composite [65].

To date, various types of graphene-metal structures are simulated by MD. Typical examples of the initial structures for MD simulations are presented in Fig. 3: (i) for layered composite different number of layers can be considered, as well as various orientations of graphene layers in the matrix, which will definitely affect mechanical properties of the

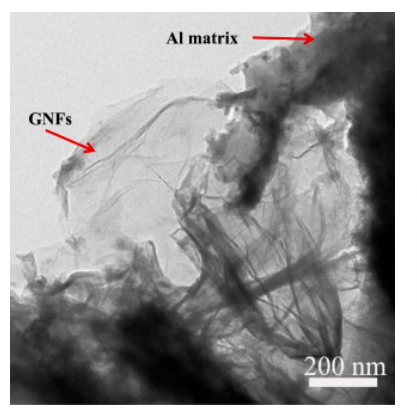

a

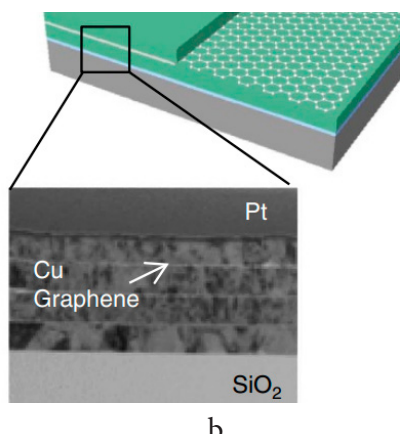

b
Fig. 2. (Color online) Experimentally obtained nanocomposites: GNFs/Al alloy nanocomposite [63] (a). By repeating the metal deposition and graphene transfer processes, $\mathrm{Cu}$-graphene nanolayered composites can be synthesized with different repeated metal thicknesses [11] (b). composite; size and edge orientation of graphene are also of high importance; (ii) the different number of grains of different sizes, but commonly of nanocrystalline size.

For example, the graphene plane can stop or initiate the propagation of dislocations which play an important role in the deformation mechanisms and significantly affect the mechanical behavior of nanocomposites. In [31], the addition of the graphene layer can considerably increase the number of the dislocations in the structure under compression and as a result, improve the strength of graphene reinforced crystal. Comparison of the structures with and without graphene at the same strain rate $10.4 \%$ are shown in Fig. 4 a. Graphene can improve the mechanical strength of multilayer $\mathrm{Cu}$ /graphene (the initial structure is similar to Fig. 3 a, tension is applied parallel to graphene layers) composites during elastic and plastic deformation stages [32].

For the case when graphene was introduced to the grain boundaries region for $\mathrm{Cu}$ matrix, it was shown that the strength limit predicted by Hall-Petch relation for $\mathrm{Cu}$ could be greatly surpassed by replacing grain boundaries with graphene (see Fig. 4 b, where the black dot is for nanocrystalline Ni, blue and purple dots are for partial reinforcement by graphene and red dot is for full reinforcement) [33].

In Fig. $4 \mathrm{c}$ the plastic deformation process of the graphene/Cu composites is shown: deformation twins were formed during deformation (under compression here, but under tension also [21]). The results are consistent with experimental observations for graphene/iron (Fig. $4 \mathrm{c}$, for the original figure - d) [67] and graphene/Cu (Fig. 4c, for the original figure - e) [68] where deformation twins are found at the interfaces. Graphene layers facilitate the formation of high-density nanotwins and give ultra-strength to the composites.

It can be concluded, that MD simulations allow to study graphene-Me composites with different structural elements. Number of graphene flakes, their orientation in a metal matrix, the chirality of GF, the distance between graphene layers in the metal matrix are the main factors affecting the mechanical properties of the composite. Presence of graphene layers can strongly affect defect dynamics in the metal matrix. Considerable increase of the number of nucleated dislocations or twins in the structure is observed for different metal matrixes.

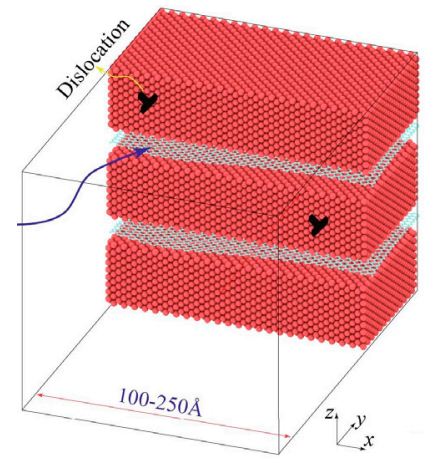

a

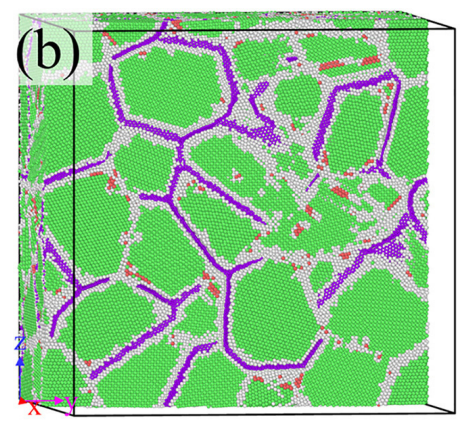

b

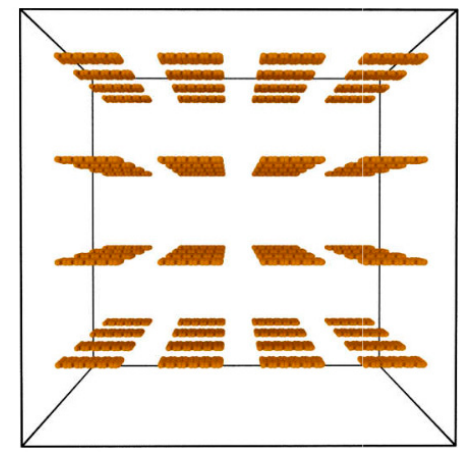

c

Fig. 3. (Color online) Possible initial structures for metal matrix strengthened by graphene. Ni combined with graphene layers [32] (a). $\mathrm{Cu}$ grains partially enclosed by graphene boundaries [33] (b). Aggregation of graphene nanoflakes in Al matrix (GNFs are shown by orange, $\mathrm{Al}$ atoms are not shown) [66] (c). 

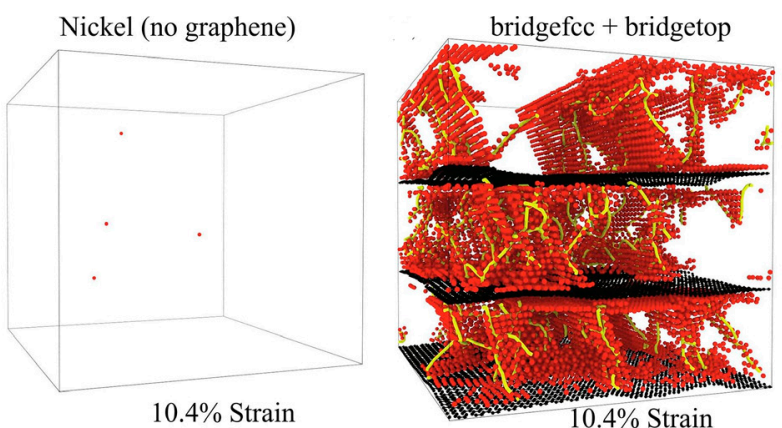

a
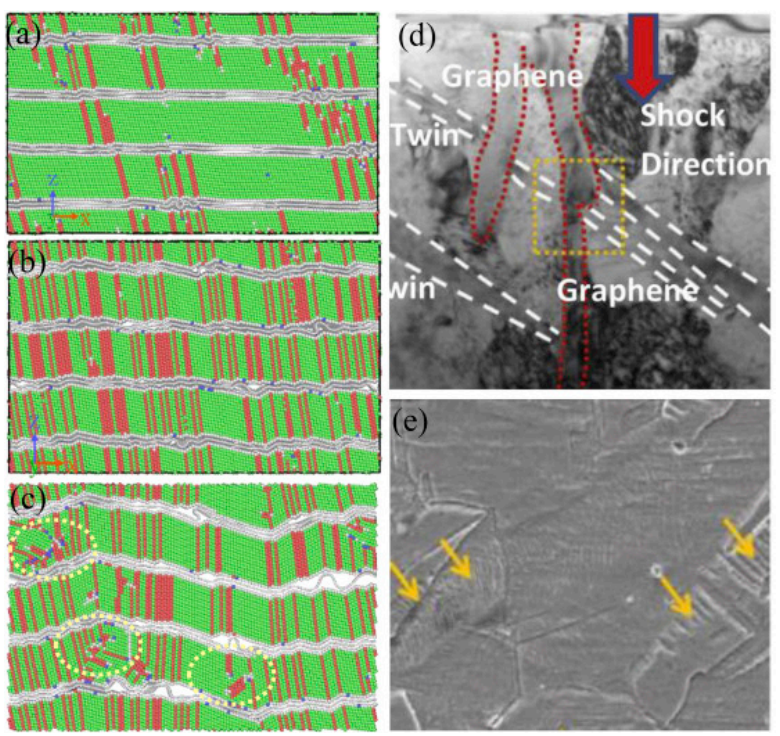

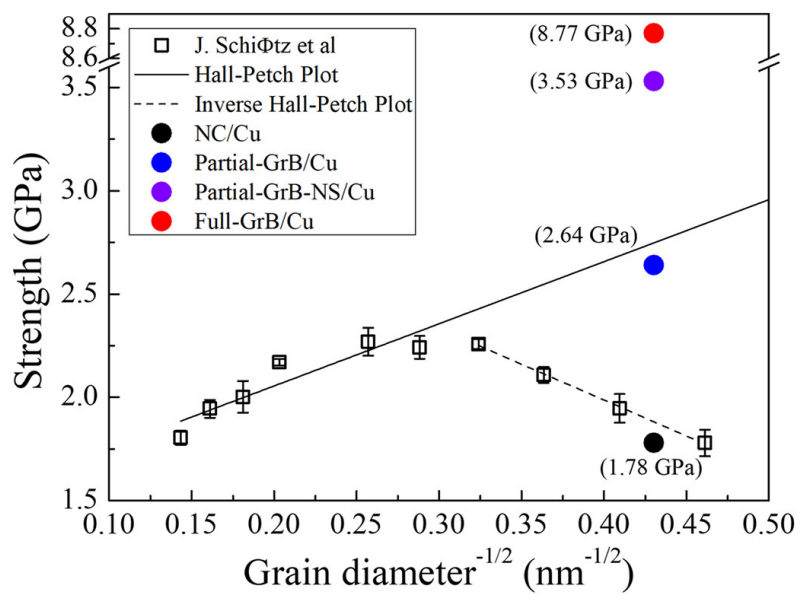

b

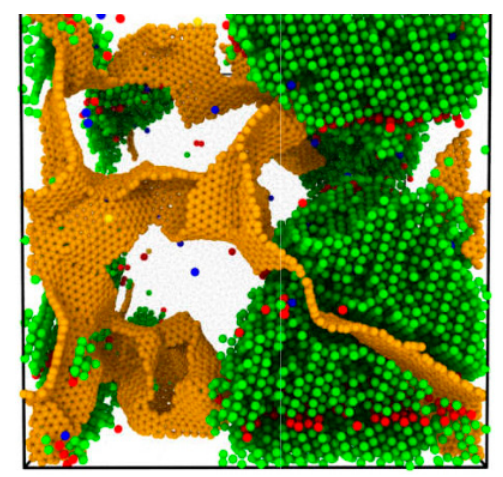

d

Fig. 4. (Color online) Ni without graphene and with three graphene layers. Propagation of dislocations under compression is shown by red color. Adopted from [31] (a). Strength as the function of grain size for Cu reinforced with graphene on the grain boundaries [33] (b). Plastic deformation process under compression (a-c form original figure), deformation twins found in (d form original figure) graphene/Fe composites under shock loading [21,67], (e form original figure) graphene/Cu composites after annealing [21,68] (c). Growth of the crystalline structure of aluminum graphene nanocomposite during cooling from 1500 to $300 \mathrm{~K}$ (the structural state at $750 \mathrm{~K}$ ). Al is shown in green, GNFs - in orange (d).

\subsection{Carbon structures as storage media for metal nanoparticles}

The combination of graphene and graphene-based aerogels with other materials can lead to the creation of new composite materials, which will have both new structural characteristics and unique properties. Such a hybrid system can have properties fundamentally different from the properties of individual structural components [69-73].

A simple method for the synthesis of bulk nanomaterial built from crumpled graphene flakes, which has an ultrahigh specific surface area $\left(3523 \mathrm{~m}^{2} / \mathrm{g}\right)$ and high conductivity, was proposed in [74]. An analysis of the structure showed that such material consists of many defective/crumpled graphene sheets several nanometers in size. It was shown that carbon atoms with $s p^{2}$ hybridization predominate in this structure, while $s p^{3}$ or $s p$ hybridization are almost not represented. Among these structures, cellular materials (aerogels) based on graphene nanoribbons are also of interest $[75,76]$. The idea of creating such morphology is quite simple and is dictated by the morphology of graphene itself, where atoms are stacked in a hexagonal lattice. As it was experimentally shown, such structures are stable and can be obtained on the basis of graphite deposition. It was already shown that cellular structures exhibit unique strength and ultrahigh extensibility [77,78].

In Fig. 5 schematic models illustrating composite structure based on graphene matrix and metal fillers are presented. Crumpled graphene and graphene aerogel are porous materials with large specific surface area and those pores can be used as cavities for metal nanoparticles.

\subsection{Graphene-Ni composite}

To consider the simulation of graphene-metal composite the following structure is chosen: crumpled graphene filled with $\mathrm{Ni}$ nanoparticles of different sizes. Three graphene flakes are shown in Fig. 6 a: the biggest possible Ni nanoparticle is shown as the projection on $x y$ and $x z$ plane. For comparison, two other structural units with nanoparticles $\mathrm{Ni}_{47}$ and $\mathrm{Ni}_{21}$ are presented. Structures, presented in Fig. 6, are not equilibrated. The size of $\mathrm{Ni}$ nanoparticles are $N_{\mathrm{NP21}}=5.5 \AA$, $N_{\mathrm{NP} 47}=7.2 \AA$, and $N_{\mathrm{NP78}}=10.5 \AA$ correspondingly. 
Then, GF with Ni nanoparticles are randomly rotated and combined into the structure of crumpled graphene shown in Fig. $6 \mathrm{~b}$ as an example. Further for simplicity, crumpled graphene (CG) filled with $\mathrm{Ni}_{78}$ will be named as CG78, with $\mathrm{Ni}_{47}$ - as CG47 and with $\mathrm{Ni}_{21}$ - as CG21. Structural unit is repeated four times along three directions with the total number of atoms in CG78 21120 with $N_{\mathrm{C}}=16128, N_{\mathrm{Ni}}=4992$; in CG47 19136 with $N_{\mathrm{C}}=16128, N_{\mathrm{Ni}}=3008$; and in CG21 17472 with $N_{\mathrm{C}}=16128, N_{\mathrm{Ni}}=1344$. To avoid the overlap, graphene flakes are placed far from each other. Thus, initial relaxation is not applied since big pores will not allow the interaction of GFs. However, those pores will disappear during further compression. It should be mentioned, that increase the size of the computation cell for two times does not lead to significant changes of the results [79-81].

All the simulations have been performed employing the molecular dynamics code LAMMPS with NVT-ensemble, held at a constant temperature of $0.1 \mathrm{~K}$ by a Nose-Hoover thermostat is used.

\section{Methods to obtain a graphene-metal composite}

Different methods are currently can be applied to carbonmetal systems to obtain composite structure: $\mathrm{Al}$ alloy reinforced by GNFs was successfully prepared via powder metallurgy approach [63]; aluminum-matrix composites reinforced with graphene nanoflakes were fabricated by cryomilling and hot extrusion processes [64]; ball milling and hot pressing to reinforce $\mathrm{Cu}$ matrix by GNFs; spark plasma sintering (SPS) and then hot rolling [65] to name a few.

MD simulation can be also applied to study the process of composite formation. In [82] migration of graphene fragments along the aluminum matrix in the solid phase is studied. In [66] process of the formation of Al-graphene composite is shown during the cooling of $\mathrm{Al}$ liquid phase with randomly oriented GFs. It was shown that the inclusion of GNFs in the aluminum matrix considerably increases the crystallization temperature from $T=570 \mathrm{~K}$ (pure aluminum) to $T=735 \mathrm{~K}$ (nanocomposite). The formation of new covalent bonds between the neighboring edges of GNFs facilitates an interconnected network of graphene nanoflakes in the $\mathrm{Al}$ matrix. This idea is very close to the composite, based on crumpled graphene with metal nanoparticles inside, since initially plane graphene flakes became crumpled in liquid $\mathrm{Al}$ phase very fast.

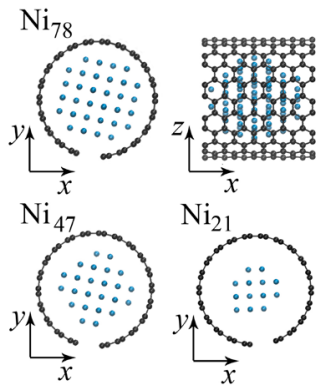

a

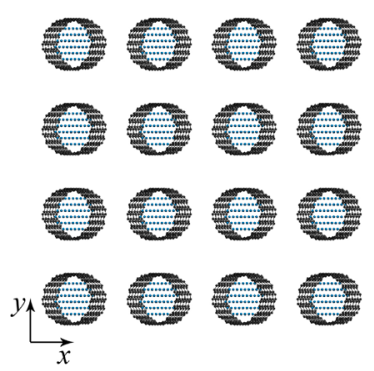

b
Fig. 6. (Color online) $\mathrm{Ni}$ nanoparticles of different sizes inside graphene flakes (a). 3D structure of crumpled graphene filled with Ni78 nanoparticles. (b) Ni atoms are shown by blue and $\mathrm{C}$ atoms are shown by black.

\subsection{Hydrostatic compression}

Here, the process of hydrostatic compression is considered for the fabrication of graphene-Ni composite, described in Section 3. Hydrostatic compression $\varepsilon_{x x}=\varepsilon_{y y}=\varepsilon_{z z}=\varepsilon$ is applied to the computational cell. The parameter $\varepsilon$ is increased at a given strain rate. After compression, the structure and mechanical properties of Ni-graphene composite are analyzed. To study mechanical behavior, hydrostatic tension is applied to the structure, obtained after compression.

In Fig. 7, pressure-strain curves for Ni-graphene systems under hydrostatic tension at $0 \mathrm{~K}$ are presented as well as the structure of the CG78 system at the corresponding strain. As can be seen, pressure-strain curves are not typical for a composite structure which means that simple compression at zero temperature cannot be used for the fabrication of the composite material based on the combination of crumpled graphene flakes and $\mathrm{Ni}$ nanoparticles. As can be seen from Fig. $7 \mathrm{~b}$, pores in the structure appear at low strain: for CG21 at $\varepsilon=0.015$, for CG47 at $\varepsilon=0.056$ and for CG78 $\varepsilon=0.005$. Structure with $\mathrm{Ni}_{47}$ nanoparticles demonstrates better behavior than two others, but also cannot be considered as the composite.

\subsection{Hydrostatic compression under high temperatures}

Further, the effect of temperature on the process of composite formation is discussed. It was found in [53] that the melting temperature of small Ni nanoclusters (less than 100 atoms) is about $1360 \mathrm{~K}$, but melting on the surface starts

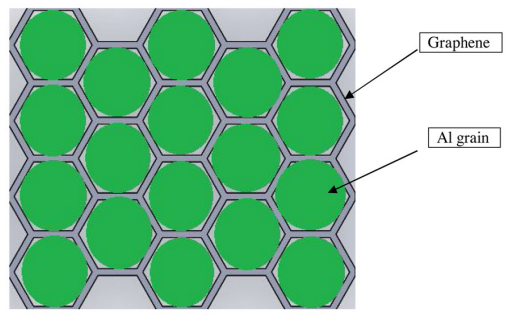

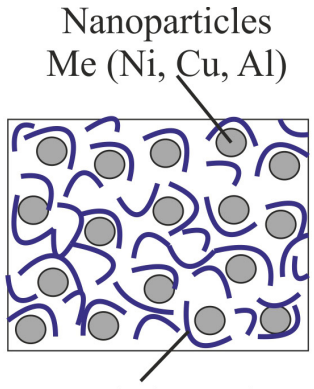

Crumpled graphene

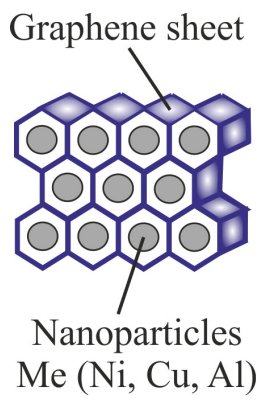

Fig. 5. (Color online) Schematic model illustrating the ideal nanostructure of Al/Gr composite [65] and composites based on graphene flakes/graphene foam and metal nanoparticles. 
earlier. Thus, at $1000 \mathrm{~K} \mathrm{Ni}_{21}$ nanoparticle starts to melt and $\mathrm{Ni}$ atoms spreading over the graphene flake surface. Bigger nanoparticles (NPs) almost fill all the space inside GNF and cannot easily spread, but melting also starts on their surface. Since temperature allows structural units to move freely and rotate it reduce the work of compression, and stresses for 1000 and $2000 \mathrm{~K}$ became lower. At high pressure, bigger NPs are also melted, their spherical form changing and the new form is governed by the movement of rigid GNFs. Close to the compression limit, $\mathrm{Ni}$ atoms are moving towards graphene flakes and fill the empty space in the structure. Moreover, at high temperatures formation of new chemical bonds between neighboring graphene flakes took place resulting in the better formation of the composite.

In Fig. 8, snapshots of composite structure are presented for CG21 and CG78 obtained by hydrostatic compression at $2000 \mathrm{~K}$, at different tension rate. It can be seen that at a temperature of $2000 \mathrm{~K}$, better mixing of structural elements occurs and annealing leads to the composite formation. Even in a structure with large nickel nanoparticles, pores are formed at much higher degrees of tension than in the absence of heating. The pores in the CG21 composite are much smaller, and, therefore, the structure is more uniform. At a temperature of $1000 \mathrm{~K}$, fraction occurs only in the region between structural elements, and at $2000 \mathrm{~K}$ it can also occur in the body of a nanoparticle since an increase in temperature led to the formation of chemical bonds between graphene flakes, and not only between flakes and nickel nanoparticles.

It also can be concluded, that the size of nanoparticles can strongly affect the process of composite formation. Interaction between NP with high surface area and GF with the same surface area lead to the formation of nanoparticles covered by graphene flake and such structural units are more rigid than, for example, small nanoparticles. Interaction between metal and graphene surface inhibits the interaction between neighboring structural elements.
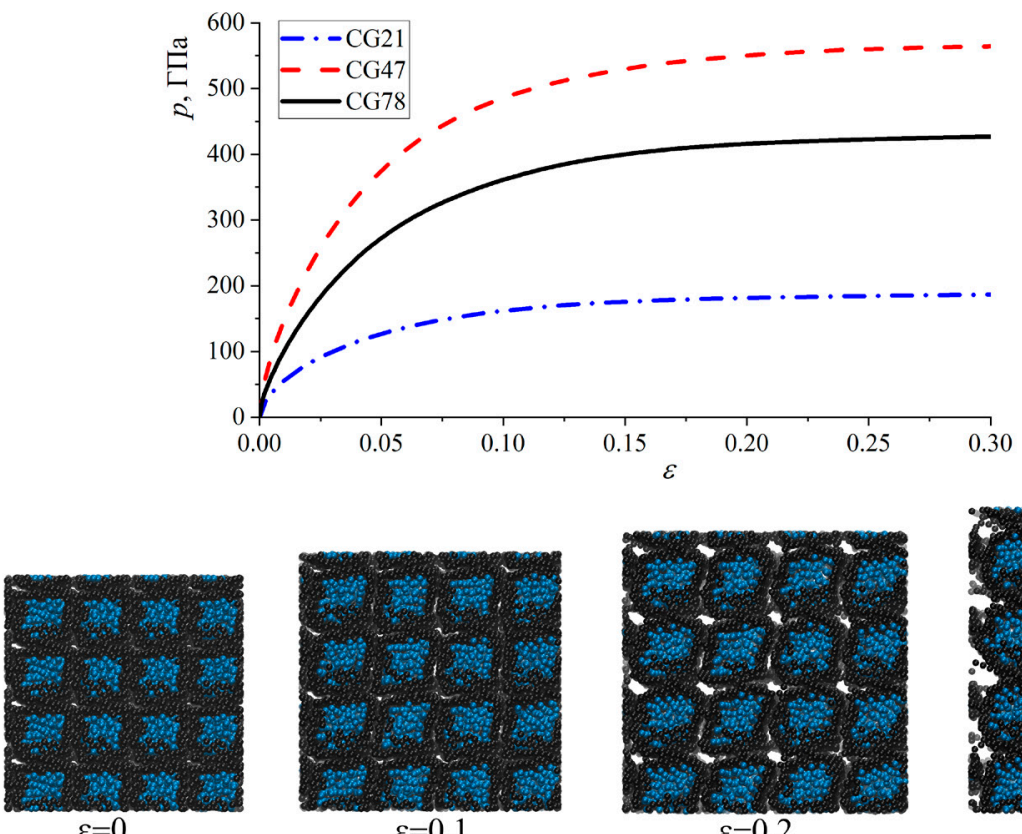

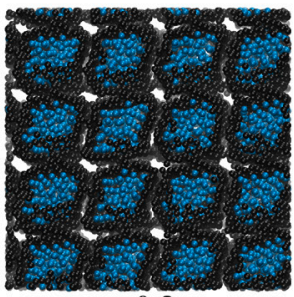

$\varepsilon=0.2$

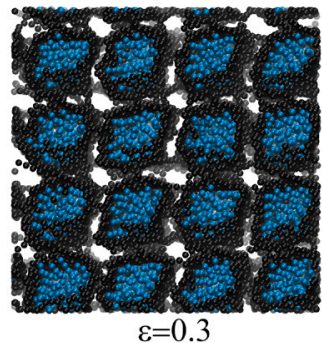

$\varepsilon=0.3$

Fig. 7. (Color online) Pressure-strain curves for Ni-graphene systems under hydrostatic tension at $0 \mathrm{~K}$ (a). Structural transformation of CG78 at the different strain (b). Ni atoms are shown by blue and $\mathrm{C}$ atoms are shown by black.
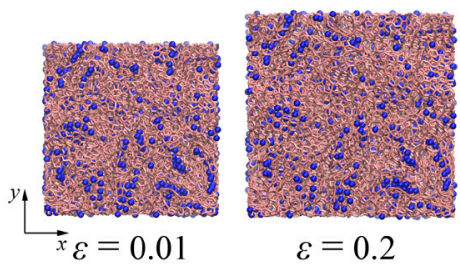

$\varepsilon=0.2$
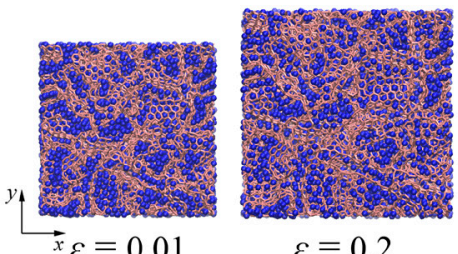

$\varepsilon=0.2$

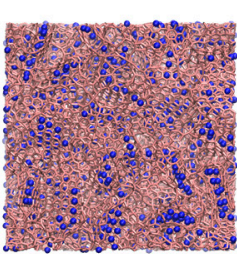

$\varepsilon=0.3$

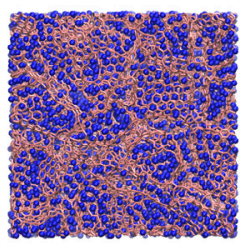

$\varepsilon=0.3$

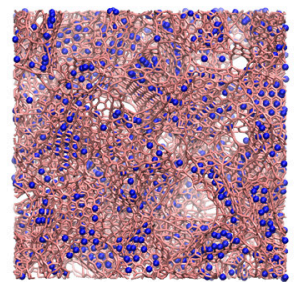

$\varepsilon=0.5$

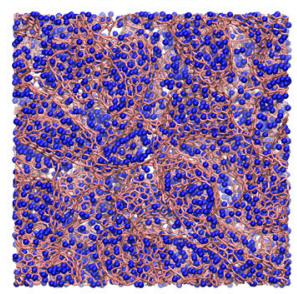

$\varepsilon=0.5$

Fig. 8. (Color online) Composite CG21 (upper row) and CG78 (lower row) as a projection on $x y$ after the tension of composite compressed at $2000 \mathrm{~K}$. 


\subsection{Effect of annealing on the fabrication of the composite structure}

Despite hydrostatic compression at $0 \mathrm{~K}$ does not lead to the formation of the composite structure, it can be also achieved by the following annealing. In the present work, annealing at 1000 and $2000 \mathrm{~K}$ is applied which can lead to the bonds reconstruction in graphene flakes and formation of new chemical bonds in the compressed structure.

In Fig. 9, pressure-strain curves are presented for the structures annealed at $1000 \mathrm{~K}$ and without annealing. As it is found, annealing considerably improves the process of composite formation. At $0 \mathrm{~K}$ structural order of carbon atoms in the basal plane is almost not disturbed. Just some edge atoms under tension are separated from graphene flake which took place just at a very high strain $\varepsilon=0.6$. This can be explained by the fact that no chemical bonds are formed after compression at $0 \mathrm{~K}$ and all structural units stay separated from each other. In comparison, at $3000 \mathrm{~K}$ internal structure of GFs considerably affected by the temperature - numerous defects have appeared, edge atoms are chemically connected to the neighboring flakes. Thus, after unloading the sample at $0 \mathrm{~K}$ the shape of structural units can be restored almost to its original form, while at $3000 \mathrm{~K}$ structural units close to the amorphous state of carbon structure with adsorbed metal atoms. The majority of edge atoms are connected to the neighboring flakes. From the structure analysis and pressurestrain curves, it can be seen that annealing even at $1000 \mathrm{~K}$ allows to obtain composite structure. Full melting of the $\mathrm{Ni}$ nanoparticle during annealing (for $T>1000 \mathrm{~K}$ ) also assists the mixing of carbon and $\mathrm{Ni}$ atoms and obtaining of the graphene-nickel composite.

In Fig. 10, snapshots of composite structure are presented for CG21 and CG78 obtained by hydrostatic compression at $0 \mathrm{~K}$ with the following annealing at $1000 \mathrm{~K}$, at different tension rates. It can be seen that for bigger NP annealing even at high temperatures close to the melting temperature of $\mathrm{Ni}$ nanoparticle, cannot lead to the composite formation. After the tension of CG78 pores are distributed regularly, while CG21 pores are randomly distributed and remain small.

Thus, annealing can be effective just for NP with a surface area much smaller than the surface area of graphene flakes, while hydrostatic compression at high temperatures is much more effective for any particle size.

\section{Conclusions}

Graphene-metal composites can be widely applied in practical applications due to their excellent mechanical and physical properties. Molecular dynamics as an effective way of studying graphene-metal composite is reviewed in the present work. It is found that MD simulation is a very common and effective way for studying Me-graphene composites. Several simulation approaches are described with the references to the mostly applied interatomic potentials.

The following conclusions can be made:

1. Simple interatomic potential can successfully be used to study deformation behavior or mechanical properties of graphene-metal composites; LJ potential is commonly used

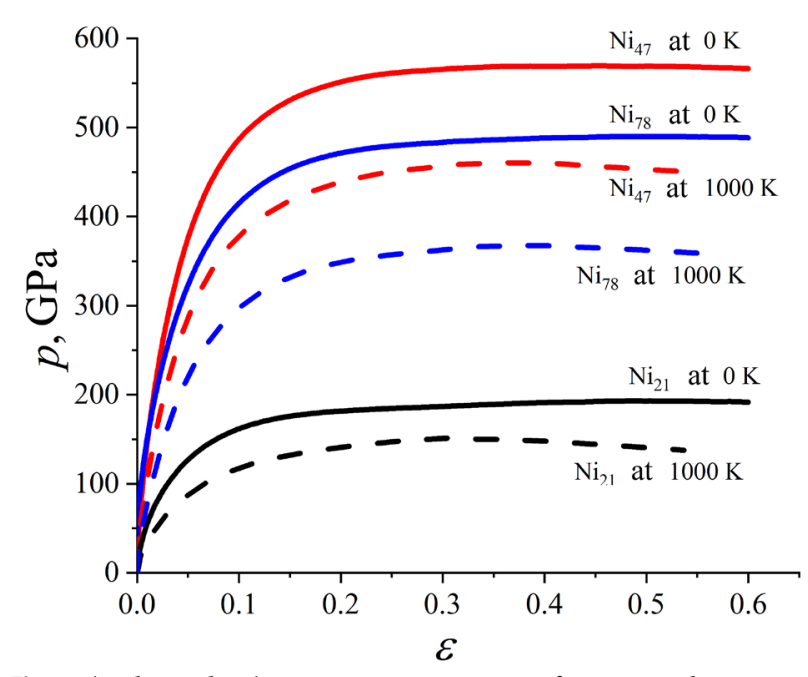

Fig. 9. (Color online) Pressure-strain curves for Ni-graphene systems under hydrostatic tension at $0 \mathrm{~K}$ and after annealing at $1000 \mathrm{~K}$.
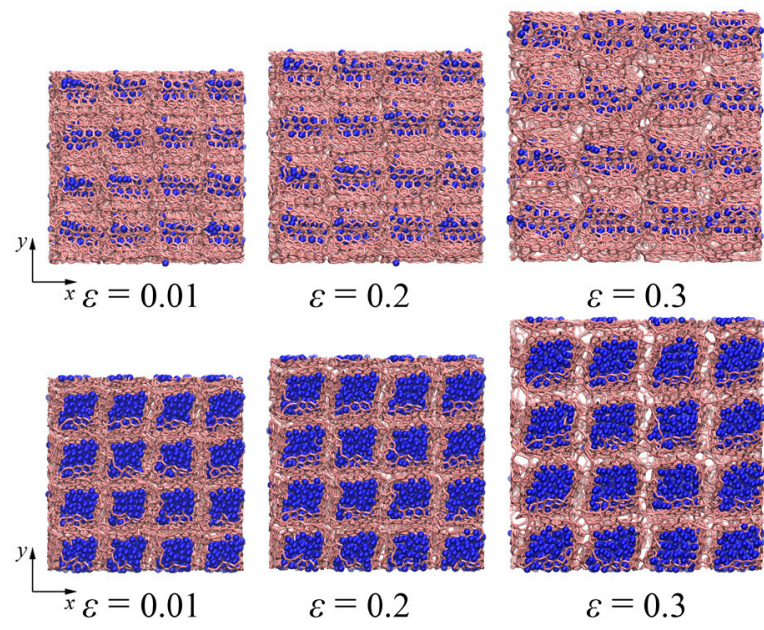

$\varepsilon=0.2$

$\varepsilon=0.3$

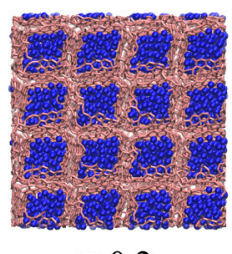

$\varepsilon=0.2$

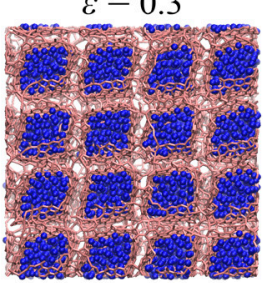

$\varepsilon=0.3$

Fig. 10. (Color online) Composite CG21 (upper row) and CG78 (lower row) as a projection on $x y$ plane after the tension of composite annealed at $1000 \mathrm{~K}$.

for $\mathrm{Cu}-\mathrm{C}$ and $\mathrm{Al}-\mathrm{C}$ interaction, because the binding energy is low, while Morse potential is used for Ni-C interaction or $\mathrm{Ni}$-Ti since the binding energy is high [83].

2. MD models are commonly used to investigate structural changes during tension/compression, revealing dislocation propagation, twin nucleation, defect dynamics, etc.

3. Mechanical properties of metal-graphene composites under tension or compression can be studied by MD simulation in a wide range of external conditions.

4. MD simulation allows to reveal the effect of the size, orientation, chirality of graphene flakes on the composite strength, which can show the possibility of improvement of mechanical properties by controlling the composite structure.

5. High-temperature treatment is an effective way to fabricate graphene-metal composite by hydrostatic compression.

Acknowledgements. Part of this research was supported by the grant of Russian Science Foundation (No. 20-72-10112). Work of M. R. R. was supported by the program of fundamental researches of Government Academy of Sciences of IMSP RAS. 


\section{References}

1. W. Hong, H. Bai, Y. Xu, Z. Yao, Z. Gu, G.Shi. J. Phys. Chem. C. 114 (4), 1822 (2010). Crossref

2. G. Williams, B. Seger, P. V. Kamat. ACS Nano. 2 (7), 1487 (2008). Crossref

3. R S. Sundaram, M. Steiner, H.-Y. Chiu, M. Engel, A. A. Bol, R. Krupke, M. Burghard, K. Kern, P. Avouris. Nano Lett. 11 (9), 3833 (2011). Crossref

4. E. H. Hwang, S. Adam, S. Das Sarma. Phys. Rev. Lett. 98, 186806 (2007). Crossref

5. S. Adam, E. H. Hwang, V. M. Galitski, S. Das Sarma. Proc. Natl. Acad. Sci. U. S. A. 104, 18392 (2007). Crossref

6. M.I. Katsnelson, F. Guinea, A. K. Geim. Phys. Rev. B. 79, 195426 (2009). Crossref

7. K.M. McCreary, K. Pi, A.G. Swartz, W. Han, W. Bao, C.N. Lau, F. Guinea, M.I. Katsnelson, R. K. Kawakami. Phys. Rev. B. 81, 115453 (2010). $\underline{\text { Crossref }}$

8. A. G. Swartz, J. R. Chen, K. M. McCreary, P. M. Odenthal, W. Han, R. K. Kawakami. Phys. Rev. B. 87, 075455 (2013). Crossref

9. P. Zhang, J.-T. Li, J.-W. Meng, A.-Q. Jiang, J. Zhuang, X.-J. Ning. AIP Adv. 7, 035101 (2017). Crossref

10. A. Klemenz, L. Oastewka, S. G. Balakrishna, A. Caron, R. Bennewitz, M. Moseler. Nano Lett. 14 (12), 7145 (2014). Crossref

11. Y. Kim, J. Lee, M.S. Yeom, J.W. Shin, H. Kin, Y. Cui, J. W. Kysar, J. Hone, Y. Jung, S. Jeon, S. M. Han. Nat. Commun. 4, 2114 (2013). Crossref

12. H. Dai, A. G. Rinzler, P. Nikolaev, A. Thess, D. T. Colbert, R. E. Smalley. Chem. Phys. Lett. 260, 471 (1996). Crossref

13. P. Nikolaev, M. J. Bronikowski, R. K. Bradley, F. Rohmund, D. T. Colbert, K. A. Smith, R. E. Smally. Chem. Phys. Lett. 313, 91 (1999). Crossref

14. Y. Ogawa, B. Hu, C.M. Orofeo, M. Tsuji et al. J. Phys. Chem. Lett. 3 (2), 219 (2012). Crossref

15. H. Ago, Y. Ito, N. Mizuta, K. Yoshida, B. Hu et al. ACS Nano. 4 (12), 7407 (2010). Crossref

16. K.S. Kim, Y. Zhao, H. Jang, S. Y. Lee, J.M. Kim et al. Nature. 457, 706 (2009). Crossref

17. T. Iwasaki, H. J. Park, M. Konuma, D. S. Lee, J.H. Smet, U. Starke. Nano Lett. 11 (1), 79 (2011). Crossref

18. S. Yoshii, K. Nozawa, K. Toyoda, N. Matsukawa, A. Odagawa, A. Tsujimura. Nano Lett. 11 (7), 2628 (2011). Crossref

19. J. Tersoff. Phys. Rev. B. 39 (8), 5566 (1989). Crossref

20. D. W. Brenner. Phys. Rev. B. 42, 9458 (1990). Crossref

21. S. J. Stuart, A. B. Tutein, J. A. Harrison. J. Chem. Phys. 112 (14), 6472 (2000). Crossref

22. J. A. Baimova, B. Liu, S. V. Dmitriev, K. Zhou. J. Phys. D: Appl. Phys. 48 (9), 095302 (2015). Crossref

23. L. Bai, N. Srikanth, E. A. Korznikova, J.A. Baimova, S. V. Dmitriev, K. Zhou. Wear. 372-373, 12 (2017). Crossref

24. G. Dhaliwal, P.B. Nair, C. V. Singh. Carbon. 142, 300 (2019). Crossref

25. H.N. Pishkenari, P.G. Ghanbari. Current Applied Physics. 17 (1), 72 (2017). Crossref

26. Z.D. Sha, P.S. Branicio, Q.X. Pei, V. Sorkin, Y. W. Zhang. Comp. Mat. Sci. 67, 146 (2013). $\underline{\text { Crossref }}$
27. A. Kuz'kin, A. M. Krivtsov. Doklady Physics. 56, 527 (2011). Crossref

28. Yu. A. Baimova, S.V. Dmitriev, A.V. Savin, Yu.S. Kivshar. Phys. Solid State. 54 (4), 866 (2012). Crossref

29. S. Weng, H. Ning, T. Fu, N. Hu, S. Wang, K. Huang, X. Peng, H. J. Qi, C. Yan. Nano Materials Science. 1 (2), 121 (2019). Crossref

30. J. Uddin, M.I. Baskes, S. G. Srinivasan, T.R. Cundari, A. K. Wilson. Phys. Rev. B. 81 (10), 104103 (2010). Crossref

31. F. Yazdandoost, A. Y. Boroujeni, R. M. Phys. Rev. Mater. 1 (7), 076001 (2017). Crossref

32. J. Charleston, A. Agrawal, R. Mirzaeifar. Comput. Mater. Sci. 178, 109621 (2020). Crossref

33. S. Zhang, P. Huang, F. Wang. Mater. Des. 190, 108555 (2020). Crossref

34. W. D. Luedtke, U. Landman. Phys. Rev. Lett. 82 (19), 3835 (1999). Crossref

35. J. Davoodi, M. Safaralizade, M. Yarifard. Mater. Lett. 178, 205 (2016). Crossref

36. Y. Shibuta, S. Maruyama. Comput. Mater. Sci. 39 (4), 842 (2007). Crossref

37. J.H. Ryu, H.Y. Kim, D.H. Kim, D.H. Seo, H.M. Lee. J. Phys. Chem. C. 114 (5), 2022 (2010). $\underline{\text { Crossref }}$

38. Z.-C. Lin, J.-C. Huang, Y.-R. Jeng. J. Mater. Process. Technol. 192-193, 27 (2007). Crossref

39. S.-K. Chien, Y.-T. Yang, C.-K. Chen. Nanoscale. 3 (10), 4307 (2011). $\underline{\text { Crossref }}$

40. Y. Shibuta, S. Maruyama. Chem. Phys. Lett. 382, 381 (2003). . Crossref

41. Y. Shibuta, J. A. Elliott. Chem. Phys. Lett. 472 (4-6), 200 (2009). Crossref

42. E. C. Neyts, A. Bogaerts. J. Phys. Chem. C. 113, 2771 (2009). Crossref

43. E. C. Neyts, A. Bogaerts. Carbon. 47 (4), 1028 (2009). Crossref

44. E. C. Neyts, Y. Shibuta, A. Bogaerts. Chem. Phys. Lett. 488 (4-6), 202 (2010). Crossref

45. S. Inoue, Y. Matsumura. Chem. Phys. Lett. 469 (1-3), 125 (2009). Crossref

46. S. Inoue, Y. Matsumura. Chem. Phys. Lett. 495, 80 (2010). Crossref

47. I. V.Lebedeva, A. A. Knizhnik, A. M. Popov, B. V. Potapkin. J. Phys. Chem. C. 116 (11), 6572 (2012). Crossref

48. R. Rezaei. Comput. Mater. Sci. 151, 181 (2018). Crossref

49. I.A. Shepelev, E.A. Korznikova, D.V. Bachurin, A.S. Semenov, A.P. Chetverikov, S. V. Dmitriev. Phys. Lett. A. 384, 126032 (2020). Crossref

50. S. Dmitriev, M. Kashchenko, J. Baimova, R. Babicheva, D. Gunderov, V. Pushin. Lett. Mater. 7 (4), 442 (2017). $\underline{\text { Crossref }}$

51. R. I. Babicheva, J. A. Baimova, S. V. Dmitriev, V. G. Pushin. Lett. Mater. 5 (4), 359 (2015). $\underline{\text { Crossref }}$

52. L. A. Girifalco, V.G. Weizer. Phys. Rev. 114 (3), 687 (1959). Crossref

53. L.R. Safina, J. A. Baimova, R.R. Mulyukov. Mech Adv Mater Mod Process. 5, 1 (2019). Crossref

54. K. K. Bejagam, S. Singh, S. A. Deshmukh. Carbon. 134, 43 (2018). Crossref 
55. K. P. Katin, V.S. Prudkovskiy, M. M. Maslov. Micro Nano Lett. 13 (2), 160 (2018). Crossref

56. A. Y. Galashev, K. P. Katin, M. M. Maslov. Phys. Lett. A. 383 (2-3), 252 (2019). $\underline{\text { Crossref }}$

57. J. Li, Y. Xiong, X. Wang, S. Yan, C. Yang, W. He, J. Chen, S. Wang, X. Zhang, S. Dai. Mater. Sci. Eng. A. 626, 400 (2015). Crossref

58. Z.H. Zhang, T. Topping, Y. Li, R. Vogt, Y.Z. Zhou, C. Haines, J. Paras, D. Kapoor, J.M. Schoenung, E. J. Lavernia. Scr. Mater. 65 (8), 652 (2011). $\underline{\text { Crossref }}$

59. F. Liu, P. B. Ming, J.Li. Phys. Rev. B. 76, 064120 (2007). Crossref

60. O.Y. Kurapova, I.V. Smirnov, E.N. Solovyeva, I.Y. Archakov, V.G. Konakov. Lett. Mater. 10 (2), 164 (2020). Crossref

61. D. I. Vichuzhanin, L.A. Yolshina, R.V. Muradymov, A. V.Nesterenko. Lett. Mater. 8(2), 184 (2018). (in Russian) [Д.И. Вичужанин, Л.А. Елшина, Р.В. Мурадымов, А.В. Нестеренко. Письма о материалах. 8 (2), 184 (2018).] Crossref

62. J. C. Sun, Z.C. Bai, Z. L. Huang, Z. P. Zhang. Lett. Mater. 10 (2), 200 (2020). Crossref

63. S. Yan, S. Dai, X. Zhang, C. Yang, Q. Hong, J. Chen, Z. Lin. Mater. Sci. Eng. A. 612, 440 (2014). Crossref

64. C. G. Lee, X. D. Wei, J.W. Kysar. J. Hone. Science. 321 (5887), 385 (2008). Crossref

65. O. Guler, N. Bagc. J. Mater. Res. Technol. 9 (3), 6808 (2020). Crossref

66. S. Kumar, S. K. Pattanayek, S. K. Das. J. Phys. Chem. C. 123 (29), 18017 (2019). Crossref

67. D. Lin, M. Motlag, M. Saei, S. Jin, R. M. Rahimi et al. Acta Mater. 150, 360 (2018). Crossref

68. H. Gao, X. Liu, Z. Ai, S. Zhang, L. Liu. Appl. Phys. A. 122, 981 (2016). $\underline{\text { Crossref }}$
69. L. Li, W. N. Sun, S.B. Tian, X.X. Xia, J.J. Li, C.Z. Gu. Nanoscale. 4, 6383 (2012). Crossref

70. C.X. Zhao, Y. Zhang, S.Z. Deng, N.S. Xu, J. Chen. J. Alloys Compd. 672, 433 (2016). $\underline{\text { Crossref }}$

71. J. J. Vilatela, D. Eder. Chem. Sus. Chem. 5, 456 (2012). Crossref

72. W. Park, C. Lee, J.M. Lee, N. Kim, G. Yi. Nanoscale. 3, 3522 (2011). Crossref

73. X. Huang, X. Y. Qi, F. Boey, H. Zhang. Chem. Soc. Rev. 41, 666 (2012). Crossref

74. L. Zhang, F. Zhang, X. Yang, G. Long, Y. Wu, T. Zhang, K. Leng, Y. Huang, Y. Ma, A. Yu, Y. Chen. Sci. Rep. 3, 1408 (2013). Crossref

75. N. V. Krainyukova. J. Low Temp. Phys. 187, 90 (2017). $\underline{\text { Crossref }}$

76. N. V. Krainyukova, E. N. Zubarev. Phys. Rev. Lett. 116 (5), 055501 (2016). Crossref

77. Z. Zhang, A. Kutana, Y. Yang, N.V. Krainyukova, E.S. Penev, B.I. Yakobson. Carbon. 113, 26 (2017). Crossref

78. X. K. Gu, Z. Q. Pang, Y. J. Wei, R. G. Yang. Carbon. 119, 278 (2017). Crossref

79. L. R. Safina, J. A. Baimova. Micro Nano Lett. 15 (3), 176 (2019). Crossref

80. K. A. Krylova, L. R. Safina. J. Phys. Conf. Ser. 1435, 012064 (2020). Crossref

81. L. R. Safina, K. A. Krylova. J. Phys. Conf. Ser. 1435, 012067 (2020). Crossref

82. A. E. Galashev, O. R. Rakhmanova, L. A. Elshina. J. Phys. Chem. B. 12 (3), 403 (2018). Crossref

83. E. D. Kurbanova, V.A. Polukhin, A.E. Galashev. Lett. Mater. 6 (4), 271 (2016). (in Russian) [Э.Д. Курбанова, B.А. Полухин, А.Е. Галашев. Письма о материалах. 6 (4), 271 (2016).] Crossref 